Empire of Friends 



\section{Empire of Friends}

Soviet Power and Socialist Internationalism in Cold War Czechoslovakia

Rachel Applebaum

Cornell University Press

ITHACA AND LONDON 
Cornell University Press gratefully acknowledges receipt of a grant from the Office of the Dean of Arts and Sciences, Tufts University, which aided in the publication of this book. Publication was also made possible in part by a grant from the First Book Subvention Program of the Association for Slavic, East European, and Eurasian Studies.

\section{Copyright @ 2019 by Cornell University}

All rights reserved. Except for brief quotations in a review, this book, or parts thereof, must not be reproduced in any form without permission in writing from the publisher. For information, address Cornell University Press, Sage House, 512 East State Street, Ithaca, New York 14850. Visit our website at cornellpress.cornell.edu.

First published 2019 by Cornell University Press

Printed in the United States of America

Library of Congress Cataloging-in-Publication Data

Names: Applebaum, Rachel, 1980-author.

Title: Empire of friends : Soviet power and socialist internationalism in Cold War Czechoslovakia / Rachel Applebaum.

Description: Ithaca : Cornell University Press, 2019. I Includes bibliographical references and index.

Identifiers: LCCN 2018029905 (print) | LCCN 2018030904 (ebook) | ISBN 9781501735585 (pdf) | ISBN 9781501735592 (epub/mobi) | ISBN 9781501735578 (cloth : alk. paper)

Subjects: LCSH: Czechoslovakia—Relations-Soviet Union. I Soviet Union-Relations-Czechoslovakia. I Socialism and culture-

Czechoslovakia. I Czechoslovakia-Civilization-Soviet influences. Classification: LCC DB2078.S65 (ebook) I LCC DB2078.S65 A67 2019 (print) I DDC 943.704—dc23

LC record available at https://lccn.loc.gov/2018029905

Cover photograph: A wounded Red Army soldier with Prague residents, May 1945. Courtesy of Národní archiv, f. 1329 [OČRA-1945], Josef Kulhánek, inv. č. 47/3. 
For Joshua 
